\title{
Market Emergence and Transition: Arbitrage, Transaction Costs, And Autarky in China's Grain Markets
}

\author{
Albert Park, Hehui Jin, Scott Rozelle, and Jikun Huang
}

\begin{abstract}
Using trimonthly Chinese provincial grain prices from 1988 to 1995, we estimate a parity-bounds model of interregional trade for four subperiods to characterize how multiple aspects of market performance change during the process of economic transition. For each period, we estimate the extent to which arbitrage opportunities are realized by traders, the transaction costs between location pairs, and the likelihood that regions do not trade. Trade restrictions cannot explain the pattern of uneven market development over time. Infrastructure bottlenecks, managerial incentive reforms, and production specialization policies, all were likely important factors affecting market performance.
\end{abstract}

Key words: arbitrage, China, grain, integration, markets, transaction costs, transition.

Over the past two decades, the common advice given to many developing and transition countries has been to liberalize markets rapidly. However, the decidedly mixed experience of countries following this advice has led to growing recognition that healthy systems of market exchange do not emerge overnight (McMillan, Blanchard). Countries liberalizing food and agricultural commodity markets, in particular, have encountered difficulties (de Alcantara; Valdes and Muir-Leresche; Jones 1995; Brooks). Markets require supporting infrastructure, institutions, and policies, and are mediated through existing social and economic relationships. In previously monopolized systems, traders require time to learn arbitrage skills and develop new market relationships. The inability of well-functioning markets to emerge immediately helps explain the large output falls that occurred in developing countries and formerly socialist countries following the introduction of rapid price and import

\footnotetext{
Albert Park is assistant professor, Department of Economics, University of Michigan. Hehui Jin is Ph.D. candidate, Department of Economics, Stanford University. Scott Rozelle is associate professor, Department of Agricultural Economics, University of California at Davis. Jikun Huang is director, Center for Chinese Agricultural Policy, Institute of Geographical Sciences and Natural Resources Research, Chinese Academy of Sciences.

The authors thank Xiao-yuan Dong, Roger Gordon, Robert Myers, Albert Nyberg, Richard Sexton, Dan Sumner, Jeffrey Williams, seminar participants at UC-Davis, and two anonymous referees for helpful comments.
}

liberalization policies. ${ }^{1}$ Although the literature describes these problems, few studies have assessed market performance in transition economies based on rigorous empirical analysis.

In China, the world's most populous developing country and largest transition economy, assessments of market performance have been mixed. On the one hand, China has been praised frequently for promoting market competition among the state-owned, collective, and private sectors (Qian and $\mathrm{Xu}$ ). Authors also have described an explosion in exchange activity in China's rural sector (Sicular). In agriculture, a large output increase rather than an output fall occurred at the beginning of the reform period. On the other hand, a recent article by Young argues that changing patterns of provincial economic structure suggest that China's markets were becoming less rather than more integrated during much of the reform period, which he attributes to internal trade barriers. Others studying trade in agricultural commodities using traditional measures of price comovement have raised similar concerns (e.g., Wan). Price distortions also have

\footnotetext{
${ }^{1}$ Blanchard and Kremer, and Roland and Verdier provide theoretical models explain output falls when managers must develop new market relationships. In the food sector, output falls occurred following liberalization in 1993 in Zambia (Seshamani), 1987 in Malawi (Chilowa), 1990 in Lithuania (Maddock), and over the past ten years in Central Asia (Babu and Tshatov).
} 
been blamed for preventing the establishment of national markets (Lin, Cai, and Li).

This emerging debate has focused attention on the need to test rather than assume that markets are working, a question of particular relevance to transition economies but important in many other contexts as well. But how to test? One approach is to look at whether spatial patterns of production are moving in the direction we would expect with freer trade (Young), although such indirect measures are subject to multiple interpretations. ${ }^{2}$ The most common tests of market integration have focused on analysis of price comovement, such as through cointegration tests. Based on short time series of price data, authors recently have used cointegration methods to evaluate the performance of markets for agricultural and food commodities in China and Russia (e.g., Gardner and Brooks; Wan; Berkowitz, Dejong, and Husted). Unfortunately, this research suffers from three problems: the interpretation of price comovement measures of market integration is conceptually problematic (discussed below), the price series are too short to estimate changing relationships over time, and the authors do not disaggregate potentially important regional effects. Examining changes over time, in particular, is essential for studying which policies and other timevarying factors affect market performance, the questions of greatest interest for understanding market development during economic transition.

This article attempts to overcome these shortcomings by developing a method that can characterize how multiple aspects of market performance change over time, enabling inference on the effect of different policies on market outcomes. We employ a maximum likelihood procedure to estimate a parity-bounds model of interregional trade for four different subperiods using a dataset of trimonthly provincial grain prices during the period 1988 to 1995 . The parity-bounds model makes it possible to directly estimate: (a) the extent to which arbitrage opportunities are realized by traders (arbitrage rate); (b) transaction costs of trade between location pairs; and (c) the percent of trading periods in which two regions do not trade

\footnotetext{
${ }^{2}$ For example, specialization may be occurring at lower levels of product aggregation, the socialist system may have had a high level of regional concentration in key sectors, and growth processes may confound simple measures of sectoral dispersion over time.
}

because price differences are less than transaction costs (autarky rate). In being the first study to look at how these different measures change over time, we are able to tell a rich story of how grain markets have developed over time in China, illuminating broader issues of market emergence and transition.

The market for grain in China provides an excellent window for examining market development during transition. Leaders relaxed restrictions on rural market trade at the beginning of China's economic reforms in 1978 and allowed interprovincial grain market trade in 1983. Institutional reforms improved the profit incentives of state grain traders over time as the government reduced the scope of its grain procurement and ration sales policies and encouraged local grain station managers to engage in commercial trading. Market institutions, such as wholesale markets, futures markets, and information systems, also developed gradually in the early 1990s. The government, however, continued to intervene strongly in grain markets to combat grain price inflation, most notably in 1988-89 and 1994-95. During these retrenchment periods, local governments erected trade barriers, implemented price controls in urban areas, and reasserted control over production and procurement of grain. Grain is one of the commodities for which internal protectionism has been widely reported (Wedeman). It is shipped long distances and so is affected by China's domestic transport bottlenecks. Commodities such as grain are ideal for studying market integration because their product homogeneity makes prices comparable in different regions and across time.

The article is organized as follows. The next section describes our strategy for modeling market performance. We then present the empirical model and estimation procedure, followed by a description of the dataset. We review China's grain market reforms and offer predictions on how reforms should affect market outcomes. Finally, the results and discussion are presented, followed by conclusions.

\section{Modeling the Market}

In well-developed markets, spatial price differences exceeding transaction costs are quickly arbitraged away by profit-seeking traders. Given a fixed transaction cost 
between two locations, there are three possible trade and price outcomes: the difference between the autarky prices in the two regions is less than the transaction cost and trade does not occur (autarky); trade does occur and the price difference between the two locations equals the transaction cost (successful arbitrage); or the price difference exceeds the transaction cost because arbitrage is not occurring (failed arbitrage). Because supply and demand conditions, policies, and transaction costs are likely to fluctuate over time, trade and price outcomes are likely to vary in different periods.

Conventional measures of market integration that focus on examining the comovement of prices in different locations (e.g., price correlations-Jones 1972; regression measures of the law of one priceRavallion; Richardson; Goodwin, Grennes, and Wohlgenant; and cointegration testsAlexander and Wyeth; Berkowitz, DeJong, and Husted; Wan) ignore much of this complexity and so are difficult to interpret (Baulch). Trade flow switches, alternating periods of autarky and trade, or fluctuating transaction costs can decrease or increase measured integration based on price comovement even when traders respond quickly to move goods when arbitrage opportunities present themselves. Also, because most locations are linked to more than one market by trade, many trade configurations are possible. These possibilities complicate the relationship between prices in two regions, so that it is unsurprising that price correlations often imply low integration even when competitive trade is observed (Faminow and Benson). Conventional measures of price comovement cannot distinguish whether lack of integration is due to failed arbitrage, autarky, or trade flow switches, although these explanations have very different implications for assessing market performance.

The first empirical models to directly examine arbitrage outcomes assess whether two locations are in the same economic market by estimating the probability that their prices differ by the transaction cost, which is stochastic (Spiller and Huang; Spiller and Wood). Prices in the two locations either differ by the transaction cost (successful arbitrage), or by less than the transaction cost (autarky). Cases of failed arbitrage are ruled out by assumption. In a transition context, however, measuring the frequency of failed arbitrage may be important if one suspects that traders are still learning how to arbitrage, lack information which prevents them from trading when price differences exceed transaction costs, or are being prevented from taking advantage of arbitrage opportunities. $^{3}$

If we define the probability of autarky, successful arbitrage, and arbitrage failure as $A U, A R$, and $A F$, then Spiller and Huang report $A R /(A U+A R)$ as a measure of integration. Baulch suggests that a more appropriate measure of integration is the arbitrage rate, or the probability that arbitrage is observed when arbitrage opportunities exist $(A R /(A R+A F))$. However, this measure, because it excludes autarky, can find two regions that only trade once in a thousand years to be integrated as long as arbitrage occurs when the opportunity presents itself. We argue that any single measure of market integration is inevitably incomplete. Rather, market performance has several characteristics that together help describe the development of the market-the arbitrage rate $(A R /(A R+A F))$, the transaction cost (or parity bound), and the autarky rate $(A U /(A U+A R+A F))$.

An advantage of our estimation procedure is its ability to estimate transaction costs directly from price data. ${ }^{4}$ Learning the actual transaction cost from interviews or secondary sources can be problematic. Individual traders are often only aware of the costs associated with some parts of the marketing chain for some trade routes during some years. Reported costs of shipping, commonly used in studies of market integration as measures of transaction costs, do not reflect costs of information, insurance, finance, or marketing. Traders also may have to pay extra fees and bribes when transport access is rationed or face risks in evading trade barriers erected by local governments. Unsurprisingly, nonparametric tests of arbitrage failure that parameterize transaction costs using freight costs find a large number of observations outside the parity bounds (Goodwin, Grennes, and Wohlgenant). Sexton, Kling,

\footnotetext{
${ }^{3}$ Sexton, Kling, and Carman extend the Spiller and Huang, and Spiller and Wood model to allow for arbitrage failure, but apply the test to a market where failures are not common (U.S. celery) and do not examine whether the probability of arbitrage failure changes over time.

${ }^{4}$ The estimated transaction cost between two locations that have a common trading partner but do not trade with each other is likely to understate the true cost. We thus restrict attention to location pairs that have direct trade flows.
} 
and Carman find that transaction costs estimated directly from price data exceed freight rates, which they suggest is due to market power even though omitted costs are equally plausible. Finally, transport as an input to trading has its own supply and demand, which can vary over time and be subject to unexpected shocks. Prices predicted by programming models that assume fixed transaction costs often are poorly correlated with actual prices (Faminow and Benson).

Our approach to modeling market integration is related to recent threshold autoregression (TAR) models that allow for "commodity points" inside of which price differences are not mean-reverting (Balke and Fomby; Obstfeld and Taylor). Both use maximum likelihood to estimate transaction costs. The TAR models, however, focus on the dynamics of price adjustment, or convergence speed assuming a constant transaction cost, whereas the parity bounds model emphasizes correctly categorizing price differences into autarky, successful arbitrage, and arbitrage failures assuming a stochastic transaction cost.

\section{Empirical Model and Estimation}

Assume that the autarky prices for two markets in a given period, $P_{t}^{1 \mathrm{~A}}$ and $P_{t}^{2 \mathrm{~A}}$, can be defined by the following reduced form equations:

$$
\begin{aligned}
& P_{t}^{1 \mathrm{~A}}=d_{t}^{1}+u_{t}^{1} \\
& P_{t}^{2 \mathrm{~A}}=d_{t}^{2}+u_{t}^{2}
\end{aligned}
$$

where $d_{t}^{1}$ and $d_{t}^{2}$ are nonstochastic elements of prices determined by supply and demand conditions in local markets, and $u_{t}^{1}$ and $u_{t}^{2}$ are zero mean stochastic disturbances to local supply and demand.

Next, define a transaction cost $T_{t}$, which is the sum of an expected component $\tau_{t}$ and a stochastic term $v_{t}$ :

$$
T_{t}=\tau_{t}+v_{t}
$$

where $E v_{t}=0, E v_{t}^{2}=\sigma_{v}$. Trade does not occur when the difference in the autarky prices of the two locations is less than the transaction cost $\left(\left|P_{t}^{2 \mathrm{~A}}-P_{t}^{1 \mathrm{~A}}\right|<T_{t}\right)$. We define the probability of this occurring at $\mathrm{t}$ as the autarky rate, denoted $\gamma_{t}$. Because there is no arbitrage in this case, the realized prices in each region are just the autarky prices:

$$
P_{t}^{1}=P_{t}^{1 \mathrm{~A}} \quad \text { and } \quad P_{t}^{2}=P_{t}^{2 \mathrm{~A}} .
$$

When the difference in autarky prices exceeds the transaction cost, i.e., $\left(\mid P_{t}^{2 \mathrm{~A}}-\right.$ $\left.P_{t}^{1 \mathrm{~A}} \mid>T_{t}\right)$, there is an opportunity for arbitrage. However, due to trade barriers, lack of information, or other impediments, arbitrage opportunities may not always lead to successful arbitrage. We denote the probability of successful arbitrage as $\lambda_{t}$, the arbitrage rate given that an arbitrage opportunity exists. With successful arbitrage, the realized prices will differ by exactly the transaction cost:

$$
Y_{t}=P_{t}^{2}-P_{t}^{1}=T_{t}=\tau_{t}+v_{t} .
$$

Here, $Y_{t}$ is defined as the realized positive price difference.

If arbitrage is unsuccessful, then $Y_{t}$ reverts to the difference in autarky prices:

$$
Y_{t}=d_{t}+u_{t}
$$

where $d_{t}=d_{t}^{2}-d_{t}^{1}, u_{t}=u_{t}^{2}-u_{t}^{1}$, and $E u_{t}=$ $0, E u_{t}^{2}=\sigma_{u}$.

Assuming $v_{t}$ and $u_{t}$ are independently and normally distributed, the likelihood function for price differences for each location pair can be written as:

$$
\begin{gathered}
L=\prod_{t}\left\{\gamma_{t}\left(1 / \sigma_{u}\right) \varphi\left(\left(Y_{t}-d_{t}\right) / \sigma_{u}\right)+\left(1-\gamma_{t}\right)\right. \\
\times\left[\left(1-\lambda_{t}\right)\left(1 / \sigma_{u}\right) \varphi\left(\left(Y_{t}-d_{t}\right) / \sigma_{u}\right)\right. \\
\left.\left.+\lambda_{t}\left(1 / \sigma_{v}\right) \varphi\left(\left(Y_{t}-\tau_{t}\right) / \sigma_{v}\right)\right]\right\}
\end{gathered}
$$

where

$$
\begin{aligned}
\gamma_{t}= & \operatorname{prob}\left(\left|P_{t}^{2 \mathrm{~A}}-P_{t}^{1 \mathrm{~A}}\right|<T_{t}\right) \\
= & \operatorname{prob}\left(u_{t}-v_{t}<\tau_{t}-d_{t}\right. \text { and } \\
& \left.u_{t}+v_{t}>-\tau_{t}-d_{t}\right) \\
= & \left.\Phi\left(\tau_{t}-d_{t}\right) /\left(\sigma_{u}^{2}+\sigma_{v}^{2}\right)^{1 / 2}\right) \\
& \left.-\Phi\left(-\tau_{t}-d_{t}\right) /\left(\sigma_{u}^{2}+\sigma_{u}^{2}\right)^{1 / 2}\right)
\end{aligned}
$$

and $\varphi$ and $\Phi$ represent the standard normal density and distribution functions. The specification defines a switching regression model in which the determinants of price difference depend on whether trade is occurring.

The estimation of the model follows Baulch and Sexton, Kling, and Carman who extend the work of Spiller and Huang 
to allow for arbitrage failure. Baulch and Sexton, Kling, and Carman use similar likelihood functions, except that Baulch makes an assumption about the value of $\tau_{t}$ whereas Sexton, Kling, and Carman estimate it (as do we). Also, Baulch allows price differences greater and less than the transaction costs (periods of failed arbitrage and autarky, respectively) to have different variances whereas Sexton, Kling, and Carman do not. Neither Baulch nor Sexton, Kling, and Carman include the variable, $d_{t}$, to describe the expected autarky price difference, and so both implicitly assume that autarky price differences are normally distributed around the transaction cost. This is reasonable for the celery market modeled by Sexton, Kling, and Carman because trade shipments are destined for markets that have no supply, and so there is no meaningful interpretation of an autarky price difference. However, it makes less sense when buyers are also producers. In such cases, if trade does not occur, then price differences should be distributed around the expected autarky price difference and not the transaction cost. ${ }^{5}$ Thus, explicit modeling of $d_{t}$ distinguishes our specification from both Baulch and Sexton, Kling, and Carman.

The maximization of the likelihood function described by (7) and (8) yields parameter estimates for $\lambda_{t}, d_{t}, \tau_{t}, \sigma_{u}$, and $\sigma_{v}$ using data only on prices $\left(P_{1 t}\right.$ and $\left.P_{2 t}\right)$. The problem is clearly underidentified, requiring that some structure be imposed on how $\lambda_{t}, d_{t}$, $\tau_{t}$ evolve over time. Typically, this is done by assuming that the underlying parameters are constant and that variation in prices and transaction costs can be captured in normally distributed disturbance terms. However, we are interested precisely in how the underlying parameters change over time during transition. The simplest way to allow the parameters to vary while providing enough structure to identify them is to define $\lambda_{t}, d_{t}, \tau_{t}$ as constants which shift at intervals that correspond to different policy regimes. Specifically, we define $\lambda_{t}, d_{t}$, and $\tau_{t}$ to be functions of

\footnotetext{
${ }^{5}$ Our selection of pairs that are expected to trade presumes that $d$ is greater than or equal to $\tau$, but this is not necessarily true for all the periods and the estimation does not impose this assumption on the data. Note that, because both autarky and failed arbitrage outcomes (the smallest and largest price differences) are distributed around $d_{t}$, the variance of $u_{t}$ should be larger than that of $v_{t}$ if both types of outcomes occur. The differences in the variances of $u_{t}$ and $v_{t}$ allows for separate identification of $d_{t}$ and $\tau_{t}$ in principle, although for some price series, $d_{t}$ is not estimated very precisely. Put another way, $d_{t}$ and $\tau_{t}$ are identified because they do not explain price differences in a way that is symmetric in the model.
}

dummy variables for four two-year periods $\left(p_{1 t}, p_{2 t}, p_{3 t}\right.$, and $\left.p_{4 t}\right):^{6}$

$$
\begin{aligned}
\lambda_{t} & =\lambda_{1} p_{1 t}+\lambda_{2} p_{2 t}+\lambda_{3} p_{3 t}+\lambda_{4} p_{4 t} \\
d_{t} & =d_{1} p_{1 t}+d_{2} p_{2 t}+d_{3} p_{3 t}+d_{4} p_{4 t} \\
\tau_{t} & =\tau_{1} p_{1 t}+\tau_{2} p_{2 t}+\tau_{3} p_{3 t}+\tau_{4} p_{4 t} .
\end{aligned}
$$

This specification posits that transaction costs and the differences in autarky prices are constant within each two-year period. Underlying demand and supply conditions may change within each period, but they must change in both provinces to the same degree, for example, due to international or national-level market shocks or policy changes. Remaining fluctuations in autarky price differences are accommodated by the error term $u_{t}$. This may be a reasonable assumption if the types of changes affecting one province but not others tend to be idiosyncratic in nature.

\section{Robustness}

Our estimates of market performance still could be sensitive to the specific structural assumptions we make about how $d_{t}$ and $\tau_{t}$ change over time (i.e., discrete jumps). The likelihood specification assumes i.i.d. normal disturbances, and misspecification might lead to a violation of this assumption, for example, if unexplained changes in transaction costs and price differences are serially correlated. It is possible that different structural assumptions about $d_{t}$ and $\tau_{t}$ would lead to different estimates of $\lambda_{t}$ and $\gamma_{t}$. To test the robustness of our results to the identification assumptions, we reestimate the model using two alternative specifications for $d_{t}$ and $\tau_{t}$. First, we allow transactions costs and autarky price differences to change within each two-year period and to be continuous between periods by modeling $d_{t}$ and $\tau_{t}$ as linear splines with respect to time. Second, we allow for serial correlation in the error terms by directly incorporating appropriate parameters in the likelihood function. The results of both models are highly consistent with those for the model described by (9).

\footnotetext{
${ }^{6}$ For computational purposes, $\lambda_{t}$ is defined as $e^{\mathrm{A} t} /\left(1+e^{\mathrm{A} t}\right)$ for $i=1,2,3$, and 4 to ensure that its value is between zero and one. ${ }^{7}$ In the linear spline formulation, in each period, $d_{t}$ and $\tau_{t}$, rather than being constant as in (9), were allowed to vary according to $d_{t}=d_{0}+\left(t-t_{0}\right) *\left(d_{1}-d_{0}\right)$ and $\tau_{t}=\tau_{0}+\left(t-t_{0}\right) *\left(\tau_{1}-\tau_{0}\right)$. The start points $d_{0}$ and $\tau_{0}$ of each period are the same as the ending points $\left(d_{1}\right.$ and $\left.\tau_{1}\right)$ of the previous period. To allow for
} 
Identification of the model also relies on distributional assumptions, specifically that the transaction cost and autarky price difference in each period can be characterized by normally distributed "errors." 8 To test the importance of this assumption, we also estimate the model assuming a gamma distribution for the error terms $v_{t}$ and $u_{t}$, and the results do not change noticeably. ${ }^{9}$

By using current prices in the two locations, our specification assumes that price adjustment occurs within 10 days, the interval of the price data. This assumption is consistent with our field interviews and the work of Luo, who observes that traders are frequently able to respond to price changes within a matter of days. In an alternative specification, we also lagged $P_{t}^{2 \mathrm{~A}}$ by 1 and 2 time periods, and found the same pattern of results.

Thus, our main results appear robust to different specification changes. Nonetheless, the results still depend on the identification assumptions, and we recognize that making a different set of assumptions could yield different results.

\section{Data}

The data come from a unique price dataset collected by China's National Market Administration Bureau (NMAB). More than 180 reporting sites from 28 of China's 30 provinces report prices of different agricultural commodities every 10 days. The prices are the average price of transactions that day in the local rural periodic market.

serial correlation, we replace $d_{t}$ and $\tau_{t}$ with the following: $d_{t}=$ $\left(1-\rho_{d}\right) * d+\rho_{d} * Y_{t-1}^{\mathrm{A}}$ and $\tau_{t}=\left(1-\rho_{\tau}\right) \tau+\rho_{\tau} * T_{t-1}$, where $Y_{t}^{\mathrm{A}}$ is the autarky price difference and $T_{t}$ is the transaction cost ( $d, \tau, \rho_{d}$, and $\rho_{\tau}$ are allowed to vary by period). The underlying assumption of these equations is that both the price shocks and transactions costs follow $A R(1)$ processes $\left(u_{t}=\rho_{d} u_{t-1}+e_{t}\right.$, $v_{t}=\rho_{\tau} v_{t-1}+\varepsilon_{t}$, where $e_{t}$ and $\varepsilon_{t}$ are iid Gaussian). Because $Y_{t}^{\mathrm{A}}$ and $T_{t}$ are not both observed at any given time, we approximate each with the actual price differences $Y_{t}$. Results with these specification changes are not reported but are available from the authors.

${ }^{8}$ These assumptions also affect the interpretation of results. For example, if there is an unusually large increase in transaction costs that lasts briefly and exceeds the "normal" variation around the mean transaction cost (e.g., government orders rail officials to give temporary priority to coal shipments in response to a severe cold spell), it will be categorized as failed arbitrage even though traders are doing the best that they can. Thus, absent information on the timing of such events, we cannot distinguish between true failed arbitrage and unusual spikes in the transaction cost.

${ }^{9}$ For computational tractability, we assume that the distribution of price differences is the same for failed arbitrage and autarky, although this need not be the case. When we use the gamma distribution, we do not impose this restriction.
The Ministry of Agriculture's Research Center for Rural Economy (RCRE) constructs provincial average prices by taking the simple average of the 5 to 10 reported individual market prices within each province. The data from individual market sites are not kept by the data collection agency and so are not available.

We examine rice and maize prices from 1988 to 1995 . These two crops are produced and consumed in nearly every province in China. Rice price data are available for 23 provinces. Because of quality differences between rice in northern and southern China, and because indica rice (the most common type of rice in southern China) is traded continuously throughout the year, the study focuses on rice markets below the Huai River. For the provinces included in the sample, rice prices are available for over 95 percent of the time periods. Data for Shanghai and Fujian are excluded due to incomplete price series. $^{10}$

Prices for maize are available for 25 provinces and almost all time periods. Product homogeneity makes it possible to include a broader geographic range of buyers and sellers (listed in table 3). For example, the sample includes a net selling province in the far northeast (Jilin) as well as a net buying province in the far southwest (Yunnan). Nominal prices from the SMAB dataset are deflated using monthly consumer price indices calculated and reported by the State Statistical Bureau. Deflation facilitates transaction cost comparisons across time and allows us to disregard transaction cost increases within periods associated with inflation.

We also conducted field work, visiting nearly every major producing and consuming region in China over several years to gain a better understanding of the institutions and policies affecting rice and maize trade and to collect information on trade patterns and transaction costs (Rozelle et al.). Interviews were conducted with national, provincial, and county grain officials, traders in buying and selling regions, transport officials (responsible for rail, trucking, and shipping), futures and wholesale market staff, managers of grain retail outlets, and local private traders in rural periodic markets. Traders in major grain

\footnotetext{
${ }^{10}$ Missing prices are troublesome because one cannot distinguish whether there was no local trade of the commodity on the survey day or there was trade but the price was not reported, a distinction which can affect interpretation of the results.
} 
exchange centers and officials in provincial capitals provided estimates of the volume and direction of grain flows and transport, handling, and other transaction costs. Interview data are used to restrict the sample to pairs of provinces that actually trade rice and maize, where appropriate disaggregate results regionally, validate our transaction cost estimates, and assist in interpreting the empirical results. ${ }^{11}$

\section{China's Grain Market Reforms and Predicted Effects on Market Performance}

To facilitate interpretation of the estimation results, in this section, we describe the government policies that affected market development during the period 1988-95 and make predictions on how these policies should affect the market outcomes of interest (arbitrage rates, transaction costs, and autarky rates). We group government policies into four categories: trade liberalization, managerial incentive reforms, market infrastructure investment, and production specialization. These policy categories can affect trade in any good. Here, we focus on grain.

The period 1988-95 was characterized by rapid growth in the volume of grain trade and in the number of traders and market centers (Sicular). ${ }^{12}$ It also was a period of very active institutional and policy changes that affected the grain trade. These included two episodes of policy retrenchments (1988-89 and 1994-95) during which the government pursued grain price stability through trade restrictions, price controls in urban areas, and a return to plan-based production and procurement of grain. Thus, if we divide the 8 -year period into four 2-year subperiods, the first and last periods can be considered periods of policy retrenchment. The second and third periods, in contrast, were periods of market liberalization, especially the third period (1992-93), when the government rapidly phased out planned rationing and procurement policies and commercialized the state trading system through institutional reforms. Policy changes in each two-year period are summarized in table 1 and are

\footnotetext{
${ }^{11}$ Because of trade flow switches, transaction cost estimates are only accurate for location pairs which trade directly.

${ }^{12}$ For example, the number of enterprises engaged in agricultural trade increased by $20 \%$ annually, the number of markets rose by $11 \%$ and the value of the goods traded in these markets (in real terms) increased by more than $30 \%$ per year.
}

key to interpreting our results, because they describe changes in trade regulations, managerial incentives, infrastructure investment (and transportation congestion), and production policies. To help the reader keep track of the different policy changes, beneath each entry in table 1 , we denote whether the direction of change in each policy in each period reflects reform that should increase market integration $(+)$, lead to retrenchment $(-)$, or have no effect $(0)$.

\section{Trade Liberalization}

China's leaders have generally supported market liberalization as a key part of the country's reform strategy. In the grain sector, interprovincial trade in grain was permitted beginning in 1983, and state traders began trading at "negotiated" (marketbased) prices in 1985. In periods of grain price stability, the government has encouraged the free flow of market grain across regions.

In times of grain price inflation, however, government officials have been quick to intervene in markets, usually to protect the purchasing power of urban residents (Rozelle et al., Wedeman). In late 1988 and 1989, the central government severely restricted trading of rice because of concerns that rapidly rising prices due to rising demand and falling production in coastal provinces would draw rice from interior provinces and put upward pressure on prices nationwide. Inland provinces blockaded the flow of rice and coastal provinces were urged to reduce their reliance on external grain supplies. These market controls led to restrictions on trade of other grains as well.

The controls did not last long. Once prices came down in the early 1990s following record harvests, market liberalization policies were pushed forward again, especially in 1992-93, when the government claimed to have fully liberalized grain market trade by eliminating planned-price procurement and sales of grain, and opening up trade in rural and urban markets (Sicular).

However, rapidly rising grain prices in late 1993 and 1994 once again led to the imposition of market barriers. Leaders in surplus provinces tried to prevent grain from leaving their localities in the hope of preventing grain prices from rising too quickly. Many urban cities in deficit areas tried to impose price controls. However, in contrast to 1988 89 , complaints were voiced by grain officials 
Table 1. Summary of Policies Influencing Grain Market Development, 1988-95

\begin{tabular}{|c|c|c|c|c|}
\hline & \multicolumn{4}{|c|}{ Years } \\
\hline & 1988-89 & 1990-91 & 1992-93 & 1994-95 \\
\hline $\begin{array}{l}\text { Trade } \\
\quad \text { Liberalization }\end{array}$ & $\begin{array}{l}\text { Tight marketing } \\
\text { restrictions }\end{array}$ & $\begin{array}{l}\text { Relaxation of } \\
\text { restrictions }\end{array}$ & $\begin{array}{l}\text { Market } \\
\quad \text { liberalization }\end{array}$ & $\begin{array}{l}\text { Local } \\
\text { protectionism } \\
\text { after rapid rise } \\
\text { in food prices }\end{array}$ \\
\hline $\begin{array}{l}\text { Direction of } \\
\text { policy change }\end{array}$ & n.a. & + & + & - \\
\hline $\begin{array}{l}\text { Managerial } \\
\text { Incentives }\end{array}$ & $\begin{array}{l}\text { Grain bureaus } \\
\text { run mainly as } \\
\text { government } \\
\text { agency, crack } \\
\text { down on private } \\
\text { traders }\end{array}$ & $\begin{array}{l}\text { Reduce policy } \\
\text { role of state } \\
\text { grain trading } \\
\text { organizations, } \\
\text { introduce } \\
\text { profit-based } \\
\text { contractual } \\
\text { incentives }\end{array}$ & $\begin{array}{l}\text { Widespread } \\
\text { commercializ- } \\
\text { ation reforms } \\
\text { and elimination } \\
\text { of quotas and } \\
\text { rationing, rise } \\
\text { of private grain } \\
\text { trade }\end{array}$ & $\begin{array}{l}\text { Reluctant } \\
\text { commercialized } \\
\text { grain agencies } \\
\text { asked to } \\
\text { implement } \\
\text { policies again }\end{array}$ \\
\hline $\begin{array}{l}\text { Direction of } \\
\text { policy change }\end{array}$ & n.a. & + & + & 0 \\
\hline $\begin{array}{l}\text { Market } \\
\text { Infrastructure } \\
\text { Investment }\end{array}$ & $\begin{array}{l}\text { Underinvestment } \\
\text { in transport } \\
\text { system (legacy } \\
\text { of Mao) }\end{array}$ & $\begin{array}{c}\text { Rail and road syst } \\
\text { establishment o } \\
\text { markets (1991) } \\
\text { markets (1993), } \\
\text { communication }\end{array}$ & $\begin{array}{l}\text { n expands } \\
\text { vholesale } \\
\text { d futures } \\
\text { iproved } \\
\text { d marketing }\end{array}$ & $\begin{array}{l}\text { Despite invest- } \\
\text { ments, reports } \\
\text { of congestion, } \\
\text { especially on } \\
\text { north/south } \\
\text { trunk lines }\end{array}$ \\
\hline $\begin{array}{l}\text { Direction of } \\
\text { policy change }\end{array}$ & n.a. & + & + & + \\
\hline $\begin{array}{l}\text { Production } \\
\text { Specialization } \\
\text { Policies }\end{array}$ & $\begin{array}{l}\text { Supply and } \\
\text { demand } \\
\text { imbalances, } \\
\text { end of lax ag- } \\
\text { first policies }\end{array}$ & $\begin{array}{l}\text { Leaders launch } \\
\text { party-led invest } \\
\text { in agriculture } \\
\text { campaign to } \\
\text { promote grain } \\
\text { self-sufficiency }\end{array}$ & $\begin{array}{l}\text { After Deng's } \\
\text { trip to South, } \\
\text { period of } \\
\text { industry-first } \\
\text { begins }\end{array}$ & $\begin{array}{l}\text { After grain price } \\
\text { inflation, local } \\
\text { self-sufficiency } \\
\text { encouraged } \\
\text { (Governor's } \\
\text { Responsibility } \\
\text { System-GRS) }\end{array}$ \\
\hline $\begin{array}{l}\text { Direction of } \\
\text { policy change }\end{array}$ & n.a. & - & + & - \\
\hline
\end{tabular}

Notes: Plus signs $(+)$ in row denote reforms in policy (or investment) that promote market development; minus signs (-) denote period of retrenchment; n.a. means no valid comparison; 0 denotes period of neither reform nor retrenchment.

in both surplus and deficit areas that the retrenchment policies were ineffective. The incentives of grain managers had changed and the market had become much larger and more difficult to control.

Trade liberalization should affect arbitrage rates, transaction costs, and autarky rates-all three dimensions of market development. Reduced barriers to interregional trade should make it easier to realize arbitrage opportunities, and should reduce transaction costs. When officials suddenly erect policy barriers to trade, those that continue to engage in trade must spend resources to evade trade barriers and bear higher risk of sanctions, temporarily increasing transaction costs. Although trade liberalization will not directly affect supply and demand elements, any policy that lowers (raises) transaction costs should also decrease (increase) the autarky rate. ${ }^{13}$

Prediction 1. Trade liberalization, or the absence of trade restrictions, will increase the arbitrage rate and reduce transaction costs (table 2, row 1).

\footnotetext{
${ }^{13}$ That is, ceteris paribus, rising transaction costs increase the price wedge between two areas, increasing the probability that the difference between the autarky prices in each region will be less than the transaction cost and that the regions will not trade. We do not describe this indirect effect in the predictions; it should be considered implicit whenever the prediction is that transaction costs increase. Other policies (e.g., production specialization policies) have direct effects on the autarky rate.
} 
Table 2. Expected Effects of Government Policies on Market Performance Measures

Arbitrage Transaction Autarky Rate $(\lambda) \quad$ Cost $(\tau)$ Rate $(\gamma)$

\begin{tabular}{llll}
\hline Trade & + & - & {$[-]$} \\
$\quad$ Liberalization & & $(-)$ & {$[-]$} \\
$\begin{array}{l}\text { Managerial } \\
\text { Incentives }\end{array}$ & + & - & {$[-]$} \\
Market & $(+)$ & & \\
$\quad$ Infrastructure & & - \\
$\quad$ Investment & & \\
Production & & \\
$\quad$ Specialization & & \\
$\quad$ Policies & & \\
\hline
\end{tabular}

Notes: The signs in the brackets in column 3 denote a secondary indirect effect of falling transaction costs on autarky rates. The signs in parentheses denote weaker secondary effects.

\section{Managerial Incentives}

In China, most commercial grain trade has been undertaken by state grain managers who manage local grain stations (Sicular). In addition to executing state procurement and rationing policies, local grain officials were allowed to engage in market trade at "negotiated" prices beginning in 1985. Since that time, the relative importance of negotiated versus planned trade has grown steadily. In the early 1990s, in many parts of China, the contractual incentives of grain managers were altered to link remuneration more closely to profitability (Park and Rozelle). The changes were motivated by a desire to encourage greater self-reliance in meeting state wage obligations in an environment of scarce fiscal resources. The institutional reforms also gave managers more control rights to choose trading partners and diversify business lines. New managerial incentives and market opportunities reduced the willingness of grain managers to implement state policies that were unprofitable during the policy retrenchment of 1994-95 (Park and Rozelle).

These institutional reforms should increase arbitrage rates, because the strengthened profit incentives should increase the motivation of managers to actively seek out profitable grain trades. Commercialization also could indirectly lead to lower transaction costs (and lower autarky rates) if improved incentives lead traders to more actively pursue cost savings in shipping grain to increase profit margins.
Prediction 2. Improved managerial incentives will increase arbitrage rates and may lead to lower transaction costs (table 2, row 2).

\section{Market Infrastructure and Services}

China's government has continuously invested in expanding market infrastructure but has struggled to keep pace with the increasing demand for roads, railways, ports, and communication infrastructure that has accompanied rapid growth. Most grain is shipped by rail and barge (for areas on the coast or along the Yangtze). Despite significant expansion of rail lines, railcar utilization remains near full capacity, with congestion worsening for the rail lines to Guangdong and other parts of southern China (author interviews). Because pricing for rail freight is regulated, side payments and queuing costs for shipping freight are likely to be significant. ${ }^{14}$

The government has also been aggressive in improving other types of infrastructure that underlie well-functioning market exchange. In the 1990s, entrepreneurial officials established new grain wholesale markets (beginning in 1991) and futures markets (beginning in 1993). These new market centers have improved the availability of information on prices in different regions and facilitated networking among major traders (e.g., Williams et al.).

Investments in transport infrastructure should reduce transaction costs by reducing the cost of shipping commodities. Lower transaction costs will indirectly reduce the autarky rate. Investments in better information should increase arbitrage rates by reducing the likelihood that managers will miss profitable trade opportunities.

Prediction 3. Investment in transport infrastructure will reduce transaction costs and investment in information will increase arbitrage rates and reduce transaction costs (table 2, row 3).

\footnotetext{
${ }^{14}$ In this case, we are referring to an informal system of sidepayments that shippers need to pay to receive a shipping permit (or access to a rail-car space-chepi zhibiao). Traders said that during periods of congestion, they typically could still purchase space on the rail car, but that more side-payments were required.
} 


\section{Production Specialization Policies}

The government's position towards regional production specialization has fluctuated over time. After years of central planning that emphasized self-sufficiency, the government significantly relaxed sown area controls in the mid-1980s when grain was plentiful and the government supported greater specialization in production (Carter and Zhong). Rice price increases in 1988 led to a rethinking of this policy as many blamed reduced grain production in the south for grain price inflation. The government urged provincial leaders to increase local supplies by increasing investments in agricultural infrastructure and adopting other policy measures (Liu). After the crisis passed in 1990, the pressure on local governments to keep up production levels also fell. Deng Xiaoping's famous trip to the south in late 1991 encouraged local leaders to specialize even further. During this time, some farmers moved from grain into cash crops and other more specialized agricultural activities. However, after the new bout of price increases in 1993-94, the government adopted a Governor Responsibility System (GRS) which made provincial governors responsible for safeguarding the food needs of their citizens. Under this system, greater self-reliance in meeting grain consumption needs was encouraged.

Specialization and trade generally go hand in hand, so that greater specialization should increase the frequency of trade and reduce the autarky rate. ${ }^{15}$ When provincial leaders aim for self-sufficiency, autarky rates should increase.

Prediction 4. Production specialization (self-sufficiency) policies will reduce (increase) autarky rates (table 2 , row 4 ).

\section{Results and Discussion}

The main estimation results are reported in table 3, which presents the average arbitrage rate, transaction cost, and autarky rate for maize and rice trading pairs for each 2-year period based on the parameter estimates from the model specified in (7)-(9). The other estimated parameters $\left(d, \sigma_{u}\right.$, and $\left.\sigma_{v}\right)$ are not of central interest and are not presented, but are available from the authors on request. Table 3 also reports average standard errors for each parameter estimate, and quick inspection reveals that all are precisely

\footnotetext{
${ }^{15}$ Higher trade volume might also affect transaction costs if there are economies of scale.
}

Table 3. Estimates of Parity-Bounds Model: China's Rice and Maize Markets, 1988 to 1995

\begin{tabular}{|c|c|c|c|c|c|c|}
\hline \multirow[b]{2}{*}{ Time Periods } & \multicolumn{2}{|c|}{$\begin{array}{l}\text { Arbitrage } \\
\text { Rate }(\lambda)\end{array}$} & \multicolumn{2}{|c|}{$\begin{array}{c}\text { Transaction Cost }(\tau) \\
\text { (1988 yuan per kilogram) }\end{array}$} & \multicolumn{2}{|c|}{$\begin{array}{l}\text { Autarky } \\
\text { Rate }(\gamma)\end{array}$} \\
\hline & Rice & $\overline{\text { Maize }}$ & Rice & Maize & Rice & Maize \\
\hline \multirow[t]{2}{*}{ 1988-89 } & 0.58 & 0.69 & 0.19 & 0.20 & 0.07 & 0.30 \\
\hline & $(0.11)$ & $(0.12)$ & $(0.03)$ & $(0.02)$ & $(0.07)$ & $(0.10)$ \\
\hline \multirow[t]{2}{*}{ 1990-91 } & 0.62 & 0.83 & 0.17 & 0.17 & 0.47 & 0.45 \\
\hline & $(0.25)$ & $(0.11)$ & $(0.02)$ & $(0.02)$ & $(0.13)$ & $(0.09)$ \\
\hline \multirow[t]{2}{*}{ 1992-93 } & 0.70 & 0.83 & 0.17 & 0.12 & 0.40 & 0.38 \\
\hline & $(0.15)$ & $(0.09)$ & $(0.03)$ & $(0.01)$ & $(0.11)$ & $(0.08)$ \\
\hline \multirow[t]{2}{*}{ 1994-95 } & 0.69 & 0.67 & 0.25 & 0.14 & 0.57 & 0.45 \\
\hline & $(0.21)$ & $(0.20)$ & $(0.04)$ & $(0.02)$ & $(0.10)$ & $(0.13)$ \\
\hline
\end{tabular}

Notes: Data are from National Market Administration Bureau's (NMAB) Rural Periodic Market Survey. Prices are reported every ten days from a number of markets in each province. Statisticians from NMAB aggregate the market-level data into a provincial average.

Rice sellers include Hunan, Hubei, Jiangxi, Anhui, and Jiangsu. Rice buyers include Zhejiang, Guangdong, Guangxi, Guizhou, Yunnan, and Sichuan. Figures are the "average of all markets," and are calculated by taking the average of the results of analysis of market development of each of the seller with each of the buyer. The results are average estimates from 30 regressions (5 sellers and each of their 6 buyers).

Maize sellers include Jilin, Liaoning, Inner Mongolia, Hebei, Henan, Shandong, Shanxi, and Shaanxi. Maize buyers include Zhejiang, Guangdong, Guangxi, Hunan, Guizhou, Yunnan, and Sichuan. The figures are "average of all markets," and are calculated by taking the average of the results of analysis of market development of each of the seller with each of the buyer. The results are average estimates from 56 regressions $(8$ sellers and each of their 7 buyers).

The periods span from the planting period in the year before the given year until the harvest of the second year (e.g., the period 1990 spans the marketing periods from November 1989 to October 1991).

The average of the parameters for all pairs of included provinces are reported. The average of the estimated standard errors for each parameter estimate are reported in parentheses. 
estimated. We focus discussion on the results for each market outcome parameter in turn, and consider the extent to which they are consistent with the predicted effects of different policies. When appropriate, we disaggregate the results by region or trading pairs. For transaction costs, we compare our estimates to costs reported in interviews. We also compare our results with those using traditional cointegration methods.

\section{Arbitrage}

Mean arbitrage rates for rice grew from 0.58 in $1988-89$ to 0.62 in $1990-91$ to 0.70 in 1992-93-steady increases consistent with trade liberalization and institutional reforms. In the last period (1994-95), however, there is virtually no change in mean arbitrage rate (0.69). The lack of any negative effect on arbitrage during a retrenchment period which saw the imposition of trade restrictions suggests that any such effects were substantially offset by positive effects on arbitrage from ongoing institutional reforms and general learning by traders. ${ }^{16}$

Arbitrage rates for maize were relatively low in 1988-89 (0.69), rose in the second and third periods (0.83), before falling in the retrenchment period, 1994-95 (0.67). Arbitrage rates thus are similar in the two retrenchment periods compared to the middle periods of greater liberalization. The reduced integration in 1994-95 is consistent with the existence of grain blockades during the period, and less consistent with a story of steady improvement in managerial incentives.

Arbitrage rates for both commodities, however, are far from 1.00, suggesting that it takes time for traders to build networks and arbitrage away profit opportunities. The difference in results for rice and maize in the last period are better understood if we disaggregate market development trends for maize into coastal and inland provinces. Almost all of the decline in the average maize arbitrage rate is attributable to trading patterns in inland regions (rice is almost all coastal) where institutional reforms were carried out less completely and retrenchment policies were better enforced (table 4). The arbitrage rate estimates suggest that highly commercialized traders in coastal regions took

\footnotetext{
${ }^{16}$ There is a slight reduction in arbitrage rates in the linear spline specification described in footnote 7 .
}

advantage of profit-making trades significantly more in 1994-95 than in the 198889 period (columns 2 and 3, row 5): while those in inland areas had recent arbitrage rates that were lower than in the late 1980s (row 11). Virtually all of the reduction in arbitrage rates in inland provinces occurred between 1992-93 and 1994-95 (rows 6 and 12). Because, the only way to ship large amounts of grain from inland provinces is by rail, inland areas likely were more vulnerable to enforcement of trade blockades. Table 4 also shows that the relative difference in the performance of coastal and interior provinces was even greater if one looks at the most important trading partners (the largest purchasers of maize for each seller), suggesting significant targeted interventions.

Finally, as an aside, we note that our estimates of levels and trends of arbitrage success are very different from those using cointegration tests, a commonly employed method that focuses on price comovement. As seen in table 3 (column 3 ) and as measured by arbitrage rates, we find virtually no change in the extent of market integration in the rice trade in Southern China between 1992-93 and 1994-95 (70\% to 69\%). Cointegration analysis, however, treats autarky periods as not integrated and finds that market integration is lower on average and declined sharply. In 1992-93, less than 50\% of the provincial pairs have prices that move together, but in $1994-95$, only about $30 \%$ of provincial pairs are integrated.

\section{Transactions Costs}

As estimated from the model, mean transaction costs in rice markets fell from 0.19 in 1988-89 to 0.17 in 1990-91, and then remained the same in 1992-93 before jumping to 0.25 in $1994-95$ (table 3 ). The transaction costs in maize trade are almost identical to those in rice trade in the first two periods, but in the third period, instead of flattening out, they continue to decrease (to 0.12). In the final period, transaction costs increase, just as for rice, but much more modestly (to 0.14). As a share of market prices, transaction costs are relatively high on average: $15-20$ percent for rice and about $25 \%$ for maize. A crude comparison of typical transport costs per kilometer per ton in 1995 using the nominal exchange rate finds that the absolute costs are several times higher in China than in the U.S., perhaps reflecting underdeveloped 
Table 4. Estimated Arbitrage Rates $(\lambda)$ between Sellers and Most Important Buyers: Maize Markets in Inland and Coastal Regions, 1988 to 1995

\begin{tabular}{|c|c|c|c|}
\hline Time Periods & $\begin{array}{l}\text { Sellers and the } \\
\text { Single Largest Buyer }\end{array}$ & $\begin{array}{l}\text { Sellers and the } \\
\text { Three Largest Buyers }\end{array}$ & $\begin{array}{c}\text { Sellers and the } \\
\text { Five Largest Buyers }\end{array}$ \\
\hline \multicolumn{4}{|l|}{ Coastal } \\
\hline $1988-89$ & 0.28 & 0.32 & 0.48 \\
\hline 1990-91 & 0.95 & 0.73 & 0.68 \\
\hline 1992-93 & 1.00 & 0.78 & 0.76 \\
\hline 1994-95 & 0.85 & 0.66 & 0.74 \\
\hline \multicolumn{4}{|l|}{ Change from } \\
\hline $88-89$ to $94-95$ & 0.57 & 0.34 & 0.25 \\
\hline \multicolumn{4}{|l|}{ Change from } \\
\hline $92-93$ to $94-95$ & -0.15 & -0.12 & -0.02 \\
\hline \multicolumn{4}{|l|}{ Inland } \\
\hline 1988-89 & 0.78 & 0.68 & 0.58 \\
\hline 1990-91 & 0.98 & 0.90 & 0.76 \\
\hline 1992-93 & 1.00 & 0.96 & 0.76 \\
\hline 1994-95 & 0.41 & 0.61 & 0.51 \\
\hline \multicolumn{4}{|l|}{ Change from } \\
\hline $88-89$ to $94-95$ & -0.36 & -0.07 & -0.07 \\
\hline \multicolumn{4}{|l|}{ Change from } \\
\hline $92-93$ to $94-95$ & -0.59 & -0.35 & -0.25 \\
\hline
\end{tabular}

Notes: For source, data description, and list of buyers and sellers, see text and table 3. Coastal transaction are between coastal sellers (Jilin, Liaoning, and Shandong) and coastal buyers (Zhejiang, Guangdong, and Guangxi). Inland transaction are between all pairs of provinces that include at least one noncoastal buyer or seller.

bulk shipping and handling capabilities, bottlenecks, or greater use of more expensive modes of transport (e.g., trucks versus rail).

The changes in transaction costs in different periods are broadly consistent with the imposition of trade barriers in the early and late periods. There do, however, remain significant differences in the estimates for rice and maize. Given that trade liberalization proceeded most rapidly during 1992-93 when the government announced that all state grain trade would be market-based, it is surprising that transaction costs in rice did not fall during this period as for maize. The ricegrowing south was probably the most open trading region in the country during this time.

Can other policies, most notably infrastructure investment and improved managerial incentives, help explain the differences? Both were unidirectional during the period of study, so are consistent with falling transaction costs in periods 2 and 3, making it difficult to distinguish among different policy effects on transaction costs in those periods. However, at first glance, they cannot explain the rising transaction costs in the last period. The market for transport and other marketing services, however, depends on both demand (from all sectors, not just grain) and supply. If rising demand outpaces supply, which has been described as a key bottleneck to growth in China (The World Bank), then high transport costs lead to higher transaction costs despite the rapid construction of new infrastructure during the period. Regional bottlenecks could affect transaction costs between different trading pairs differently. In interviews with grain traders, we were told that in the mid-1990s, congestion on China's long-distance train, truck, and shipping networks had risen to such critical levels, especially in the booming south (the center of the rice trade), that traders had to pay high premia to guarantee access to rail car or barge space, which more than doubled the freight and handling charges. The likely importance of transport bottlenecks rather than trade restrictions in explaining estimated transaction costs is well-illustrated by the case of rice trade in Guangdong, the province adjacent to Hong Kong and one of the largest buyers on China's interprovincial rice markets. The estimated transaction cost for rice trade with its three major suppliers-Hunan, Jiangxi, and Hubei-rise rapidly in 1992-93 (the period before retrenchment-table 5). Even in the 1988-89 period, marketing costs from Guangdong's nearest neighbor, Hunan, are above the average transaction cost for all rice trades $(0.22$ versus 0.19$)$, suggest- 
Table 5. Estimated Transaction Costs for Rice Shipments to Guangdong Province, 1988 to 1995

Transaction Costs $(\tau)$

(1988 yuan per kilogram)

Supplying

Province $\quad 1988-89 \quad 1990-91 \quad 1992-93 \quad 1994-95$

\begin{tabular}{lllll}
\hline Hunan & 0.22 & 0.20 & 0.27 & 0.39 \\
Jiangxi & 0.28 & 0.24 & 0.40 & 0.41 \\
Hubei & 0.31 & 0.28 & 0.36 & 0.35 \\
\hline
\end{tabular}

ing that congestion is a persistent problem in southern China. Regional bottlenecks in transport thus can help explain why average transaction costs did not fall in 1992-93 for rice, but continued to fall for maize. Many maize suppliers are northeastern provinces that ship by ocean barge rather than by rail. It is impossible to distinguish with our data how much of the rise in transaction costs in 1994-95 was due to these same factors or to trade barriers. However, rail bottlenecks in the south are consistent with a greater increase in rice transaction costs compared to maize.

The size and significance of the average transaction cost estimates demonstrate their reasonableness and the value of using our statistical techniques for measuring them (table 6). Eighteen traders in 10 provinces reported to the authors the costs of mov- ing grain between pairs of markets on a per kilogram (for the average trade) and per metric ton (MT) per kilometer basis during 1994-95. The correlation coefficient between the statistically-estimated and interview-reported transaction costs for the same provincial pairs in the same period is 0.865 , which provides confidence that the method is capturing true variation in underlying transaction costs. The survey-based estimates for rice $(0.115$ per kilogram and 0.103 per MT per kilometer), however, are less than half of the econometrically estimated results $(0.254$ and 0.234 -table 6 , columns 1 and 2). Respondents apparently are not able or willing to quantify all of the variable costs that go into making up the rice price spread between two regions, such as insurance, search costs, bribe fees to get port access, congestion premia, etc. On the other hand, maize estimates calculated by the two methods do not differ statistically. ${ }^{17}$

\section{Autarky}

Autarky rates for the two crops change over time in a way that differs from arbitrage rates and transaction costs. For both commodities, autarky rates rise in the second period, fall in the third, and rise in the fourth (table 3, columns 5 and 6). The increase in autarky

${ }^{17}$ Transaction cost estimated by the linear spline model are 0.224 for rice and 0.138 for maize.

Table 6. Comparison of Estimated Transaction Costs (1994-1995) and Transaction Costs from Trader Interviews (1994)

\begin{tabular}{|c|c|c|c|c|}
\hline & $\begin{array}{c}\text { Mean } \\
\text { Estimated } \\
\text { Transaction } \\
\text { Cost (T) } \\
\text { (yuan) }\end{array}$ & $\begin{array}{c}\text { Mean } \\
\text { Transaction } \\
\text { Cost from } \\
\text { Trader } \\
\text { Interviews }(\tau) \\
\text { (yuan) }\end{array}$ & $\begin{array}{c}\text { Mean Percentage } \\
\text { Difference between } \\
\text { Estimated and } \\
\text { Interview Transaction } \\
\text { Costs }\left(100^{*}(\mathrm{~T}-\tau) / \mathrm{T}\right) \\
(\text { percent })\end{array}$ & $\begin{array}{l}\text { Correlation } \\
\text { between } \\
\text { Estimated } \\
\text { and Interview } \\
\text { Transaction } \\
\text { Costs } \rho(\mathrm{T} . \tau)\end{array}$ \\
\hline \multicolumn{5}{|l|}{ Rice } \\
\hline $\begin{array}{l}\text { Total transaction costs } \\
\text { by weight (per kg) }\end{array}$ & $\begin{array}{c}0.254 \\
(0.115)\end{array}$ & $\begin{array}{c}0.115 \\
(0.016)\end{array}$ & +113 & 0.865 \\
\hline $\begin{array}{l}\text { Transaction costs by } \\
\text { weight-distance } \\
\text { (per MT per km) }\end{array}$ & $\begin{array}{c}0.234 \\
(0.156)\end{array}$ & $\begin{array}{c}0.103 \\
(0.035)\end{array}$ & & \\
\hline \multicolumn{5}{|l|}{ Maize } \\
\hline $\begin{array}{l}\text { Total transaction costs } \\
\text { by weight (per kg) }\end{array}$ & $\begin{array}{c}0.138 \\
(0.076)\end{array}$ & $\begin{array}{c}0.164 \\
(0.049)\end{array}$ & -17 & 0.735 \\
\hline $\begin{array}{l}\text { Transaction costs by } \\
\text { weight-distance } \\
\text { (per MT per km) }\end{array}$ & $\begin{array}{c}0.064 \\
(0.030)\end{array}$ & $\begin{array}{c}0.078 \\
(0.015)\end{array}$ & & \\
\hline
\end{tabular}


in 1990-91 is not predicted by the timing of trade liberalization and improved managerial incentives or by the fall in transaction costs. The fall in autarky in rice during 1992-93 also does not correspond with the unchanging transaction cost. These inconsistencies suggest that other policies, such as those affecting production of grain directly, may be influencing autarky rates.

Changes in policies affecting production specialization match observed patterns in autarky rates. Rising incomes, prorural policies, and relaxation of mandatory production and marketing quotas in agriculture in the mid-1980s increased the demand for food, including grain, and allowed supplies to fall in some areas along the coast of China. By the late 1980s, national and regional supply and demand imbalances combined with trade restrictions led to spiking grain prices and wide price gaps among regions, helping to explain the low autarky rates. ${ }^{18}$ Before and after the Tiananmen crisis in 1989, as grain prices soared, more than doubling the previous 40-year high, the government decided to cool industrial expansion and refocus investment and organization in agriculture in the south, a reversal of the specialization policies that were designed to increase agricultural production only in those provinces with comparative advantage in grain production. New enthusiasm for old-style, agriculture-first measures, however, quickly dissipated after Deng's trip to Guangdong in late-1991, a move that sent a clear signal to the officials, especially those in coastal areas, that they could once again pursue production specialization policies and concentrate on industrial development without fear of political reprisal. In 1994, however, real prices of grain again rose rapidly, and national and regional leaders took decisive steps to regain control of the grain economy using traditional policy tools (Chen), re-instituting procurement quotas and encouraging greater grain production in the south. Provinces, however, did not respond uniformly to such policies. Autarky rates in some of the fastest growing coastal provinces either continued to fall (e.g., Guangdong's rate fell by 10 percent) or stayed the same (e.g., Guangxi). In contrast, autarky rates of inland rice buyers all rose; that for Yunnan Province, for example, rose by $50 \%$.

\footnotetext{
${ }^{18}$ Recall that lack of trade when prices exceed transaction costs is failed arbitrage, not autarky, in our model.
}

\section{Conclusions}

In this article, estimation of arbitrage rates, transaction costs, and autarky rates from a parity-bounds model of interregional grain trade in China, informed by detailed knowledge of trade flows, policy changes, and regional differences, has made possible a rich characterization of market emergence during transition. Our results highlight the dangers of simple attribution of observed outcomes to one factor alone, such as trade barriers, and of regional aggregation without sensitivity to regional differences.

Even with our multiple measures of market outcomes, a simple reading of our results might lead to the conclusion that markets in 1995 have not developed much since 1988. Arbitrage rates and transaction costs have not changed much on average, and autarky rates have increased. Clearly, it is a mistake to take market development for granted; traders take time to learn and policies must be supportive across multiple dimensions for market competition and trade to flourish.

However, this also misses much of what is important in a more nuanced interpretation of what is happening in China's grain markets. China's grain markets have grown dramatically over time in terms of the number of participants and the volume of trade. The development of the market has been uneven over time, with periods of liberalization punctuated by periods of retrenchment. However, market development and changes in the managerial incentives of state traders, especially in southern China, may have matured to a point that traditional policy interventions are less effective and more costly. Arbitrage rates in the south did not fall with retrenchment in 1994-95, and much of the increases in transaction costs may be due to transport bottlenecks in the south. Thus, there is no strong evidence that trade barriers have driven market outcomes during the period under study, although they have received greatest attention (Young).

By comparing the estimation results with our knowledge of China's grain policy reforms, we find evidence that infrastructure bottlenecks in the south production specialization policies, and lagging managerial incentive reforms and market deepening in interior regions, all have affected grain market performance in China, and merit attention. Here, we see most clearly the advantages of tracking changes in multiple measures of market performance over time and 
for different regions. We do, however, recognize that other unobserved factors changing over time could also be affecting the outcomes we observe.

The characterization of market development in China presented here highlights the complexity of the process. In China, grain market development has been gradual, both by choice (i.e., retrenchment) and because of infrastructure bottlenecks. We are unable, however, to consider the extent to which this gradual approach has been optimal. There have been and continue to be obvious costs to policy interventions in the grain trade, but these must be evaluated in the broader context of the political economy of economic reform.

\section{[Received March 2000; accepted June 2001.]}

\section{References}

Alexander, C., and J. Wyeth. "Cointegration and Market Integration: An Application to the Indonesian Rice Market." J. Develop. Stud. 30(January 1994):303-28.

Babu, S.C., and A. Tashmatov. "Attaining Food Security in Central Asia-Emerging Issues and Challenges for Policy Research." Food Policy 24(August 1999):357-62.

Balke, N., and T. Fomby. "Threshold Cointegration." Int. Econ. Rev. 38(August 1997):627-45.

Baulch, B. "Transfer Costs, Spatial Arbitrage, and Testing for Food Market Integration." Amer. J. Agr. Econ. 79(May 1997):477-87.

Berkowitz, D., D. DeJong, and S. Husted. "Quantifying Price Liberalization in Russia." J. Comp. Econ. 26(December 1998):735-60.

Blanchard, O. The Economics of Post-Communist Transition. New York: Oxford University Press, 1997.

Blanchard, O., and M. Kremer. "Disorganization." Quart. J. Econ. 112(November 1997):10911126.

Brooks, J. "Policies and Institutions in Transition Economies: A Political Economy Perspective on the Agri-food Sector." Food Policy 20(1995):487-500.

Carter, C.A., and F. Zhong. "China's Past and Future Role in Grain Trade." Econ. Develop. Cultur. Change 39(July 1991):791-814.

Chen, X. "The Central Government's Politics and Measures are Good, but it is Difficult to
Implement them at the Local and Departmental Level." Liaowang 18(1994):13-16 (in Chinese).

Chilowa, W. "The Impact of Agricultural Liberalization on Food Security in Malawi." Food Policy 23(December 1998):553-69.

de Alcantara, C.H., ed. Real Markets: Social and Political Issues of Food Policy Reform. London: Frank Cass, 1993.

Faminow, M.D., and B.L. Benson. "Integration of Spatial Markets." Amer. J. Agr. Econ. 72(February 1990):49-62.

Gardner, B.L., and K.M. Brooks. "Food Prices and Market Integration in Russia: 1992-93." Amer. J. Agr. Econ. 76(August 1994):641-46.

Goodwin, B.K., T.J. Grennes, and M.K. Wohlgenant. "A Revised Test of the Law of One Price Using Rational Price Expectations." Amer. J. Agr. Econ. 72(May 1990):682-93.

Jones, S. "Food Market Reform: the Changing Role of the State." Food Policy 20(1995): 551-60.

Jones, W.O. Marketing Staple Food Crops in Tropical Africa. Ithaca: Cornell University Press, 1972.

Lin, J., F. Cai, and Z. Li. The China Miracle: Development Strategy and Economic Reform. Hong Kong: Chinese University Press, 1996.

Liu, J. A Summary of China's Ninth 5-year Plan for Agriculture. Beijing: China Agricultural Press, 1991.

Luo, X. "Market Integration and Grain Policy Reform: A Case Study of the Rice Market in South China." PhD dissertation, University of Minnesota, 1999.

McMillan, J. "Markets in Transition." Advances in Economics and Econometrics: Theory and Applications. David Kreps and Kenneth Wallis, eds. Cambridge: Cambridge University Press, 1995.

Maddock, N. "Agriculture after Socialism: The Transformation and Development of Lithuanian Agriculture.” Food Policy 20(1995): 129-37.

Obstfeld, M., and A. Taylor. "Nonlinear Aspects of Goods-Market Arbitrage and Adjustment: Heckscher's Commodity Points Revisited." J. Jpn. Int. Econ. 11(December 1997):441-79.

Park, A., and S. Rozelle. "Reforming StateMarket Relations in Rural China." Econ. Trans. 6(November 1998):461-80.

Qian, Y., and C. Xu. "Why China's Economic Reforms Differ: The M-Form Hierarchy and Entry/Expansion of the Non-state Sector." Econ. Trans. 1(June 1993):135-70. 
Ravallion, M. "Testing Market Integration.” Amer. J. Agr. Econ. 68(February 1986):102-109.

Richardson, D. "Some Empirical Evidence on Commodity Arbitrage and the Law of One Price.” J. Int. Econ. 8(1978):341-51.

Roland, G., and T. Verdier. "Transition and the Output Fall.” Econ. Trans. 7(January 1999):1-28.

Rozelle, S., A. Park, J. Huang, and H. Jin. "Bureaucrats to Entrepreneurs: The Changing Role of the State in China's Grain Economy." Econ. Develop. and Cultur. Change 48(January 2000):117-252.

Seshamani, V. "The Impact of Market Liberalisation on Food Security in Zambia." Food Policy 23(December 1998):539-51.

Sexton, R.J., C. Kling, and H.F. Carman. "Market Integration, Efficiency of Arbitrage, and Imperfect Competition: Methodology and Application to U.S Celery." Amer. J. Agr. Econ. 73(August 1991):568-80.

Sicular, T. "Redefining State, Plan, and Market: China's Reforms in Agricultural Commerce." China Quart. 144(December 1995):1020-46.

Spiller, P.T., and C.J. Huang. "On the Extent of the Market: Wholesale Gasoline in the Northeastern United States." J. Indust. Econ. 34(December 1986):131-45.
Spiller, P.T., and R.O. Wood. "The Estimation of Transaction Costs in Arbitrage Models." J. Econometrics 39(November 1988): 309-26.

Valdes, A., and K. Muir-Leresche, eds. Agricultural Policy Reform and Regional Market Integration in Malawi, Zambia, and Zimbabwe. Washington D.C.: International Food Policy Research Institute, 1993.

Wan, G. "Rice Market Integration in China." Unpublished manuscript, University of Sydney, 1997.

Wedeman, A., ed. "Regional Protectionism: Translations." Chinese Econ. Stud. 26(1993):3-104.

Williams, J.C., A. Peck, A. Park, and S. Rozelle. "The Emergence of a Futures Market: Mungbeans on the China Zhengzhou Commodity Exchange." J. Futures Markets 18(June 1998):427-48.

The World Bank. At China's Table: Food Security Options. Washington, DC: The World Bank, 1997.

Young, A. "The Razor's Edge: Distortions and Incremental Reform in the People's Republic of China." Quart. J. Econ. 115(November 2000):1091-1135. 